\title{
Enhancing Export Performance: Betting on Customer Orientation, Behavioral Commitment, and Communication
}

\begin{abstract}
This study examines the extent to which behavioral commitment and communication mediate the effect of customer orientation on export performance such as satisfaction with the percentage margin, capability of payment, and level of complaints. The research was carried out in the Norwegian seafood industry with a sample of 105 exporters. Length of the relationship, firm size and environmental uncertainties are considered as covariates. The results show that behavioral commitment and communication fully mediate the relationship between exporter's customer orientation and customer's payment capability. Furthermore, communication mediates the relationship between customer orientation and the level of customer complaints. The results do not support the view that behavioral commitment and/or communication are key mechanisms promoting exporter's satisfaction with the margins. The more predictable and stable the environment is in the export market, the more likely it is that the exporter is pleased with the level of complaints and the percentage margin.
\end{abstract}

Keywords: Behavioral commitment, communication, customer orientation, export performance, seafood, Norway, PLS 


\section{Introduction}

Achieving high levels of performance in an exporting context is a major challenge because of physical distance and cultural differences between independent business partners, and different competitive situations (Bello, Chelariu, \& Zhang, 2003; Leonidou, Samiee, Aykol, \& Talias, 2014; Racela, Chaikittisilpa, \& Thoumrungroje, 2007; Zhang, Cavusgil, \& Roath, 2003). Research focusing on relational elements as mechanisms in the management of activities between independent business partners belongs to the relational paradigm, also referred to as the behavioral perspective (Styles, Patterson, \& Ahmed, 2008). The relational paradigm has its foundation in the relational contracting theory developed by Macneil (1978). According to this view, doing business is not only concerned with discrete economic transactions based on price as an incentive and system of information, but also involves longterm relational exchange. Maintaining long-term business relationships is considered more efficient than being constantly searching for new partners (e.g. Granovetter, 1985). Researchers associated with the Industrial Marketing and Purchasing Group developed the interaction approach, which also emphasizes the importance of developing and maintaining a close and long-term relationship in a buyer-seller context (e.g. Håkansson, 1982; Leonidas, Katsikeas, \& Hadjimarcou, 2002; Styles \& Ambler, 1994). This study, which focuses on ongoing business relationships in an exporting context, is rooted in the theoretical perspectives claiming that longterm business relationships benefit the independent partners involved in the business relationship.

Commitment is considered to be one of the key constructs in the relational paradigm (e.g. Dwyer, Schurr, \& Oh, 1987; Leonidou et al., 2014; Morgan \& Hunt, 1994). The partners involved in a business relationship characterized by a high level of commitment are dedicated to a close and lasting relationship with each other (Kim \& Frazer, 1997b), and they are willing to put effort into the relationship to ensure that it lasts indefinitely (Dwyer et al., 1987; Morgan 
\& Hunt, 1994). Most of the studies focusing on the individual components have investigated the attitudinal aspects of commitment - in terms of being affective, calculative, normative, and instrumental - while the behavioral aspect of commitment has received limited attention (e.g. Bloemer, Pluymaekers, \& Odekerken, 2013; Brown, Lusch, \& Nicholson, 1995; De Ruyter, Moorman, \& Lemmink, 2001; Geyskens, Steenkamp, Scheer, \& Kumar, 1996; Kim, Hibbard, \& Swain, 2011; Styles et al., 2008). However, the studies carried out by Kim and Frazier (1997a; 1997b) are exceptions. Among other things, they investigated the role of industrial distributors' behavioral commitment in a national market. Recent studies conducted in an exporter-importer context investigate the role of calculative and affective commitment (Bloemer et al., 2013; Styles et al., 2008). No research has so far investigated the consequences of behavioral commitment, nor its role in an exporting context.

Based on research reported in the organizational and marketing channels literature, Kim and Frazier (1997a) identified behavioral commitment to be one out of three key components of commitment in marketing channel relationships (the other two were continuance and affective commitment). Behavioral commitment refers to the extent to which the exporter demonstrates high commitment to the business relationship by offering special assistance when the importer asks for it (Kim \& Frazier, 1997a; 1997b). In the Norwegian export seafood industry, providing special assistance may include extended credit, flexible payment schedules, and acceptance of unfavorable orders, i.e. irregular deliveries and volumes that are less than fixed minimum volumes. The Norwegian seafood export industry operates in a global market that is highly competitive, and multi-sourcing is a common practice among importers (Pettersen, 2005). Strengthening the tie with one's business partner by offering help when the partner asks for it could be one feasible approach to the development of a stable and long-term business relationship. However, sustaining this kind of commitment is time consuming and costly, as it requires allocation of significant human and financial resources (Leonidas et al., 
2002; Skarmeas, Katsikeas, \& Sclegelmilch, 2002). Investigating the extent to which offering special support to a buyer influences the exporter's performance in a positive way is therefore highly relevant from a managerial perspective.

Communication, which refers to open sharing of information, is considered a key behavioral construct, playing a vital role in developing business relationships in a cross-cultural context. Communication leads to improved coordination, commitment, cooperation, and performance, and higher level of trust (e.g. Anderson \& Weitz, 1989; Coote, Forrest \& Tam, 2003; LaBahn \& Harich, 1997; Leonidou et al., 2014; Nes, Solberg, \& Silkoset, 2007; Phan, Styles, \& Patterson, 2005; Zhang et al., 2003). Communication is essential to achieve success in relationships crossing national borders because of the difficulties of understanding the needs of remote customers (LaBahn \& Harich, 1997). Therefore, extending the knowledge base regarding the role of communication in a cross-cultural context is highly relevant (Voss, Cullen, Sakano, \& Takenouchi, 2006). Furthermore, research shows that communication is an essential input to the development of commitment in business relationships crossing borders (e.g. Leonidou et al., 2014; Nes et al., 2007; Styles et al., 2008). The relationship between communication and behavioral commitment has not been examined in previous research, neither has their joint effect as mediators in a cross-border context.

Customer-oriented firms emphasize understanding and meeting the needs of their customers (Narver \& Slater, 1990). Customer-oriented organizations achieve profitability through creating superior value for their customers by offering the best solutions to customers' needs (e.g. Day, 1994; Narver \& Slater, 1990; Zhou, Brown, Dev, \& Agarwal, 2007). Offering the best solutions includes responding to customer inquiries in an effective way and resolving customer complaints (Parasuraman, 1987). Moreover, the quality of the products must be secured from the point in time it is ordered until the delivery reaches the customer, and the products must be delivered in a minimum of time without errors. Consequently, the logistics, 
delivery systems, and services supporting these systems need to be continuously developed and maintained (Slater \& Narver, 1994).

Although it is recognized that customer orientation is a driver of performance (Hult \& Ketchen, 2001; Kumar, Venkatesan, \& Leone, 2011; Slater \& Narver, 1994; Sousa, MartinezLopez, \& Coelho, 2008; Zhou et al., 2007), research indicates that it is not clear how customer orientation relates to performance. Some studies conducted in an exporting context report a direct positive relationship (e.g. Cadogan, Diamantopoulos, \& Siguaw, 2002; Rose \& Shoham, 2002), while a study carried out by Solberg and Olsson (2010) reveals a negative relationship. Recent studies suggest that investigating the mechanisms that mediate the relationship between customer orientation and performance has a potential value (Hortinha, Lages, \& Lages, 2011; Murray, Gao, \& Kotabe, 2011; Racela et al., 2007; Smirnova, Naudè, Henneberg, Mouzas, \& Kouchtch, 2011). Evidence shows that customer orientation is essential in building high quality relationships characterized by satisfaction, trust, commitment, cooperative norms, and cooperation (e.g. Blesa \& Bigné, 2005; Bigné, Blesa \& Küster, \& Andreu, 2004; Racela et al., 2007; Siguaw, Simpson, \& Baker, 1998). Besides, studies show that relational behaviors mediate the customer orientation - performance relationship (e.g. Baker, Simpson, \& Siguaw, 1999; Cross, Brashear, Rigdon, \& Bellenger, 2007; Racela et al., 2007). However, we still have limited knowledge about the relational qualities through which customer orientation influences performance, especially in an exporting context (Racela et al., 2007). Consequently, one of the objectives of this study is to extend this knowledge base by introducing behavioral commitment and communication as possible mediators in the customer orientation - export performance relationship.

Furthermore, we have limited knowledge with respect to what kind of performance measures are likely to be influenced by behavioral commitment and communication. A frequently used approach to measure export performance is to adopt a scale that captures the 
multi-faceted nature of performance (e.g. Cavusgil \& Zou, 1994; Nes et al., 2007; Styles, 1998). A few studies have investigated the link between antecedent factors and the individual export performance measures, such as sales growth, profitability, and the level of satisfaction (Cooper \& Kleinschmidt, 1985; Cadogan et al., 2002; Hult \& Ketchen, 2001; Madsen, 1989). Findings show different results for the individual measures of performance, claiming for the necessity of understanding how exporters can attain specific performance objectives (Cadogan et al., 2002; Cooper \& Kleinschmidt, 1985; Madsen, 1989). Consequently, the second objective is to examine separately three different export performance measures considered to be essential for the industry under study (margins achieved from the customer, the customer capability of payment, and the customer level of complaints).

Summing up, this study contributes to the literature and practice by: (1) integrating two streams of research (relationship marketing and market orientation paradigm) in order to extend our knowledge base regarding how the exporter can achieve satisfactory performance; (2) bringing new knowledge concerning the individual and joint mediating effects of behavioral commitment and communication in the customer orientation - export performance relationship; (3) shedding light on the question whether it is beneficial to invest in behavioral commitment and communication to achieve satisfactory performance in terms of margins, paying capability, and level of complaints, and (4) proposing practical directions to exporters.

\section{Development of hypotheses}

\subsection{The mediating effect of behavioral commitment}

\subsubsection{Customer orientation and behavioral commitment}

Narver and Slater (1990) were among the first to carry out research to examine the market orientation concept, and customer orientation was one of the key components. Customer orientation is concerned with sufficient understanding of one's target customers and behaviors 
necessary for the creation of superior value for the buyer (Narver \& Slater, 1990). Customer orientation is a key marketing capability which is embedded in the practices and routines of the exporting firm, providing a source of competitive advantage that is highly needed in competitive markets (Day, 1994; Hult \& Ketchen, 2001; Pelham, 2000).

Behavioral commitment is one key component of commitment and implies strengthening ties with a business partner by providing special assistance when this partner asks for it (Kim \& Frazier, 1997a; 1997b). Offering special assistance can be viewed as a kind of input and implicit pledge, which declares a commitment to the relationship (Anderson \& Weitz, 1992; Dwyer et al., 1987; Kim \& Frazier, 1997a). The supplying firm does not only perform its predetermined roles, but also offers special support when the buying firm asks for it, required by different situations (Noordewier, John, \& Nevin, 1990).

Customer-led organizations are concerned about establishing and maintaining relations with customers to achieve high performance (Grönroos, 1989). Customer orientation, which involves offering solutions (products and services supporting the deliveries) that match the customers' needs, promotes commitment in the business relationship (Siguaw et al., 1998; Taylor et al., 2008). Dealing with customers' needs involves activities that bring suppliers and customers closer to each other (Grönroos, 1989; Håkansson, 1982; Steinman, Deshpandè, \& Farley, 2000). An exporter with a high level of customer orientation is inclined to perform activities that go beyond status quo and involve helping customers that are in a difficult situation (Han, Kim, \& Srivastava, 1998; Pierce \& Delbecq, 1977). Performing practices that demonstrate the value of your customer result in a high level of relational behaviors such as commitment (Kumar, Scheer, \& Steenkamp, 1995), and providing help when the customer asks for it could be one way to express commitment to the relationship (Kim \& Frazier, 1997a; 1997b). 


\subsubsection{Behavioral commitment and performance}

Export performance reflects the outcomes of export behavior and is an essential guide for a firm analyzing the extent to which it succeeds in its markets (Diamantopoulos, 1998). Performance measures can be viewed as non-financial and subjective (i.e. productive and rewarding, satisfaction with the decision to export, export success) (e.g. Bianchi \& Saleh, 2010; Cavusgil \& Zou, 1994; Skarmeas et al., 2002; Styles et al., 2008). Export performance measures can also be classified according to financial and objective measures, which implies that the respondent reports actual figures (i.e. sales growth, profitability, return on investment, etc.) (e.g. Cavusgil \& Zou, 1994; Hult \& Ketchen, 2001), and financial and subjective measures that capture the extent to which the respondent perceives various financial achievements to be satisfactory (i.e. profitability of the operation, change in the profitability, sales growth, market share, etc.) (e.g. Nes et al., 2007; Styles et al., 2008). In our study, the performance measures can be viewed as subjective and financial measures that refer to the extent to which the firm is satisfied with the percentage margins achieved from the selected customer, the customer's capability of paying, and the customer's level of complaints.

Commitment implies stability and a long-term orientation toward the relationship, and performance improves as the relationship moves towards a close and committed partnership (e.g. Lothia, Bello, Yamada, \& Gilliland, 2005; Nes et al. 2007; Skarmeas et al., 2002). Exporters are likely to be engaged in the relationships they are committed to in order to ensure success (Skarmeas et al., 2002), and firms can improve performance in the export markets by offering support to their customers (Cavusgil \& Zou, 1994; Madsen, 1989). Expending efforts on the relationship helps reduce the separation between the two independent firms, which facilitates better performance (Rosson \& Ford, 1982). Commitment demonstrates the importance of the relationship to the exporting firm through the expended efforts leading to better financial performance (Nes et al., 2007). Buyers who attain special attention from their 
supplying firm are likely to reward the supplying firm with higher margins (Lohtia et al., 2005). Showing willingness to understand and flex to the particular situation of the customer improves customer satisfaction (Humphreys \& Williams, 1996). Providing assistance, such as a payment schedule compatible with the customer's economic situation, will be appreciated by the customer and will motivate him her to expend the necessary efforts to meet the terms related to the payment schedule (Frazier, 1983). Eventually, this will satisfy the exporter with the customer's capability of paying. Furthermore, by offering assistance when the foreign buyer is in need, the exporter demonstrates that the firm is prepared to be involved with the buyer in a long-term perspective resulting in a productive business relationship (Skarmeas et al., 2002), which could imply a lower level of complaints. The following hypotheses are proposed:

H1. Behavioral commitment mediates the relationship between customer orientation and the extent the exporter is satisfied with:

1) the percentage margin achieved from this customer.

2) this customer's capability of paying.

3) this customer's level of complaints.

\subsection{The mediating effect of communication}

\subsubsection{Customer orientation and communication}

Communication is defined as the extent to which the partners of a business relationship openly share information. Open communication is present when both business partners share information that is of any use to the other party (LaBahn \& Harich, 1997). A high level of communication is considered to be of great importance in relationships crossing borders because geographical and cultural distances involve some challenges in understanding each

other's needs (LaBahn \& Harich, 1997; Skarmeas et al., 2002). Information shared may involve the inventory situation, product qualities, pricing structures, market conditions, and 
promotional activities (Mohr \& Nevin, 1990). Also unexpected information about any new environmental demands that may affect the other party is provided, thus enabling the parties to cope with a new situation accordingly (Dwyer et al., 1987).

A key issue in customer-led organizations is to base activities on the needs of the customers (Grönroos, 1989), and paying attention to customers' needs implies close contact with customers (Solberg \& Olsson, 2010). A high level of customer orientation implies a twoway relationship between the customer and the supplying firm (Steinman et al., 2000; Strong \& Harris, 2004), and market driven suppliers must be prepared to exchange information continuously with their customers (Day, 1994). The customer-oriented firm responds to the buyers' inquiries and complaints (Siguaw, Brown \& Widing, II 1994), which forms the basis from where also other kinds of information important to the business venture are exchanged (Evangelista, 1994). Customer orientation promotes customer-oriented sales behavior, which implies communication that involves understanding the situation of the customer (e.g. Cross et al., 2007). Consequently, a firm's customer orientation influences personnel behavior towards its customers in a positive way, and communication is a part of this behavior.

\subsubsection{Communication and performance}

Communication is an essential governing mechanism in relational exchange (e.g. Bello et al., 2003; Zhang et al., 2003), and the level of performance depends upon how well business partners communicate with each other (LaBahn \& Harich, 1997). High level of communication between business partners facilitates better understanding of how the goals and the requirements of the relationships can be met (Leonidou, Palihawadana, Chari, \& Leonidou, 2011). Communication is considered as one of the key constructs of cross-cultural relationships because it is essential in the process of establishing and sustaining successful relationships in competitive markets (LaBahn \& Harich, 1997; Phan et al., 2005; Voss et al., 2006). Exchange 
of information, which reflects a strong working relationship between exporters and importers, promotes sales and profit goals (Bello et al., 2003). Moreover, communication helps the exporter stay informed about the buyer's situation, which means that accommodations can be made when necessary (Bello et al., 2003). Thus, the level of customer's complaints could be kept on a low level, and the customer's paying capability could be known to the exporter and eventually dealt with. The following hypotheses are proposed:

$\mathbf{H}_{2}$. Communication mediates the relationship between customer orientation and the extent to which the exporter is satisfied with:

1) the percentage margin achieved from this customer.

2) this customer's capability of paying.

3) this customer's level of complaints.

\subsection{The joint mediating role of communication and behavioral commitment}

Commitment is an important stabilizing factor in supplier - distributor relationships (e.g. Anderson \& Weitz, 1992). However, establishing relationships with reliable distributors in export markets is a major challenge (Evangelista, 1994). Two-way communication is one feasible approach to establishing long-term business relationships with desired distributors in international markets (Nes et al., 2007). Provision of useful information requires time and efforts put into exchanging information (Anderson \& Weitz, 1992; Goodman \& Dion, 2001), and these kinds of efforts bring business partners closer to each other, making the partners motivated to stay in the business relationship (Anderson \& Weitz, 1992). Consequently, exchange of meaningful information should be encouraged because it leads the business partners to adopt a long-term outlook and focus on future goals of the business venture (Anderson \& Weitz, 1992; Coote et al., 2003). 
A few studies demonstrate how the individual components of commitment, such as affective and calculative commitment, could be sustained by communication between independent business partners (De Ruyter et al., 2001; Styles et al., 2008; Voss et al., 2006). Likewise, we expect that communication also enhances behavioral commitment. High level of communication involves not only access to local market knowledge, demand trends, and so on, but also to an understanding of the buyer's needs that could be related to logistics, deliveries, and processing of documents (Dwyer et al., 1987; Heide \& John, 1992). Exporters are motivated to commit to a relationship characterized by high level of information sharing (Anderson \& Weitz, 1992), and offering support when the customer needs it is one way of signalling the exporter's motivation to maintain the relationship (Kim \& Frazier, 1997a; 1997b). Thus, we expect that communication and behavioral commitment function as joint mediators in a customer orientation - performance relationship. ${ }^{1}$ We propose the following hypotheses:

H3. Communication and exporter's behavioral commitment jointly mediate the relationship between customer orientation and the extent to which the exporter is satisfied with:

1) the percentage margin achieved from this customer.

2) this customer's capability of paying.

3) this customer's level of complaints.

\subsection{Control variables}

We controlled for three covariates as follows: length of relationship, firm size, and environmental uncertainties in the market of the selected customer. Length of relationship leads to improved export performance (Gripsrud, Solberg, \& Ulvnes, 2006). Over time, the exporter and the importer get to know each other, and performance is enhanced due to the learning effect

\footnotetext{
${ }^{1}$ The arguments supporting the relationship between customer orientation and communication and behavioral commitment and the three performance measures are the same as those presented in the sections 2.2.1 and 2.1.2, respectively.
} 
(Katsikeas, Skarmeas, \& Bello, 2009). We postulate that the longer the business relationship is, the better is the perceived performance. The size of the firm expresses its capability of absorbing the costs of marketing and achieving economies of scale (Agarwal \& Ramaswami, 1992). We argue that firms with larger resources are in a better bargaining position, which makes them prepared to attain higher levels of performance. Environmental uncertainty refers to the external uncertainty the exporting firm is faced by in the foreign market (Aulakh \& Kotabe, 1997; Rindfleisch \& Heide, 1997). Evidence shows that environmental uncertainty has both positive and negative effect on export performance (Raven, McCullough, \& Tansuhaj, 1994). We postulate that environmental uncertainty has an effect on the perceived performance.

Figure 1 presents the conceptual model.

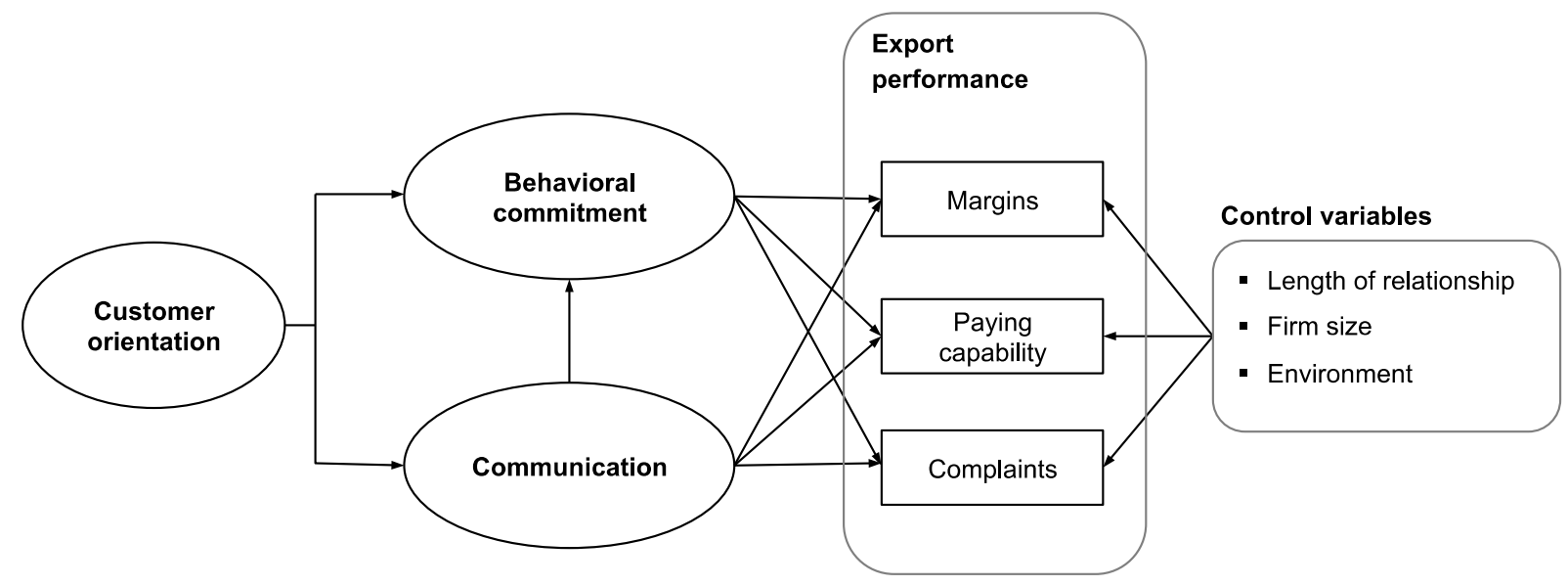

Fig. 1. The conceptual model (exporter's point of view)

\section{Method}

\subsection{Sampling frame}

Norwegian exporters of seafood products and selected ongoing business relationships in export markets provide the empirical context for our research. By focusing on one single industry, this study allows us to control for the effect of industry (Balakrishnan, 1996; Medlin, Aurifeille, \& Quester, 2005). The unit of analysis is the ongoing relationship between the respondent and the selected customer. The perspective of the selling side has been taken into 
account to assess the exporting firm's customer orientation, behavioral commitment, and export performance, as well as the communication taking place between the respondent and the selected customer.

The sampling frame was developed on the basis of a list held by the Norwegian Seafood Council. The effective sample consisted of 271 exporting firms. Every firm was contacted by telephone, and 224 accepted to respond. It was clarified both by phone and by instructions given in the questionnaire that the person responsible for a specific business relationship was the one who should report. This person was considered to be the key informant in terms of being the most knowledgeable person because of her/his pivotal point of contact with the buyer in the importing firm (Styles et al., 2008).

In this study the respondent was asked to select a business relationship with duration of two years or more. Two years is the minimum recommended by researchers when ongoing business relationships are under investigation (O'Grady \& Lane, 1996). Researchers maintain that developing relationships across national borders and cultures takes time (Skarmeas et al., 2002; Styles et al., 2008), and for the performance to be evaluable, the business relationship must have been sustained for some time. There is a lack of consensus regarding choice of strategy to avoid getting uniformly positive data (e.g. Nes et al., 2007; Skarmeas et al., 2002; Zhang et al., 2003). The instructions used in our study are inspired by the study carried out by Skarmeas et al. (2002). The following instructions were given: If the respondent serves three or less customers in export markets with duration of two years or more, the respondent should select the customer who bought the largest volume seafood products the previous year. If the respondent serves 4 or 5 customers with duration of two years or more, the respondent should select the customer who bought the second largest volume the previous year. If the respondent serves more than 5 customers with duration of two years or more, the respondent should select the customer who bought the third largest volume the previous year. 
A questionnaire, including a cover letter and a pre-paid envelope, was sent to each of the respondents. Participants in the survey were ensured anonymity. In total, 112 responded to the questionnaire. 78 responded after the first wave of questionnaires, 23 responded after the second, and 11 responded after the third wave. Two questionnaire responses were excluded due to missing data, and three responses were excluded because the business relationships had been running for one year or less. Two questionnaire responses were excluded in the analysis stage because the squared Mahalanobis distance scores were substantially different from the others (Byrne, 2010). 105 observations were included in the analysis, which makes up a response rate of 38.7 per cent. A test of non-response bias, a $t$-test of mean differences across the early and late response groups, showed that there are no significant differences for number of employees, export sales experience, and key constructs included in the conceptual model at the significance level of 0.05 (Armstrong \& Overton, 1977).

$54.6 \%$ of the respondents reported they were the general manager/director, $36.1 \%$ reported they were the sales manager/marketing director, and $6.5 \%$ reported they were a sales representative. $2.8 \%$ of the respondents did not report their position. On average, the respondents had 12.5 years of export experience. Two of the respondents did not report their export experience. The exporting firms had an average of 21.25 employees, which implies that the sample mainly consists of small firms. The respondents reported that $63.8 \%$ of the customers were wholesalers, while $36.2 \%$ of the customers were retailers, processing companies, and others.

\subsection{Scales}

Multi-item scales and a 5-point response format were used to operationalize the variables. Customer orientation, behavioral commitment, communication, and performance are anchored by very poor description and very good description. Customer orientation is a new 
scale. Two studies have been used as sources to establish the customer orientation scale consisting of 4 items: Deshpandé, Farley and Webster (1997) and Parasuraman (1987). Behavioral commitment consists of three items, and they have been derived from Skarmeas et al. (2002). Two studies have been used as the sources of 5 items to capture communication: Heide and John (1992) and LaBahn and Harich (1997).

Evaluating export performance is considered to be a complex task, and the extent to which the assessment is useful depends on the credibility of the measures (Lages, 2000). Established measures such as growth, volume, and strategic and competitive position were presented to 6 exporters in preliminary interviews to get their point of view on these measures. The comments were that these measures were not considered relevant, primarily because of the small size of the firm. Export performance is therefore assessed on the basis of three measures that were established on the basis of these interviews.

The duration of the business relationship, which is one of the control variables, is a continuous variable on the number of years that the firm has been involved with a specific business partner, and it is logarithmically transformed. Firm size, which is a second control variable, is also a continuous variable on the number of employees, and it is logarithmically transformed. Environmental uncertainty is a formative scale consisting of 4 items. Demand trends are anchored by very difficult to predict to very easy to predict. Import controls, rate of exchange, and economic development are anchored by very unstable and very stable. Import controls are derived from Aulakh and Kotabe (1997), and the other three items capturing the external environment are established on the basis of interviews with exporters.

Interviews were carried out with 6 key persons in different export firms to ascertain that the theoretical constructs would be relevant for the context studied (Shankarmahesh, Mahesh, Ford, \& LaTour, 2004). The items included in the questionnaire were translated into Norwegian and then back-translated into English. The questionnaire was pre-tested by 4 persons 
responsible for sales of seafood products in export markets to identify any possible problems and to ensure that the scales were accommodated to the current context studied (Chang, Witteloostuijn, \& Eden, 2010). Some changes regarding formulations were carried out as a result of feedbacks. A comprehensive list of items including means and standard deviations are shown in table A.1 (see appendix A).

\subsection{Measurement validation}

Because the sample was relatively small, the analysis was run by using Partial Least Squares statistical approach in SmartPLS 2.0 (Ringle, Wende, \& Will, 2005). To assess the $t$ values and the significance levels of the coefficients, we used a non-parametric bootstrap procedure with sample size $=105$ and bootstrap sample $=5000$ (Hair, Ringle, $\&$ Sarstedt, 2011) First, a confirmatory factor analysis was conducted to test the reliability and validity of the measures. To assess the reliability of the reflective constructs, the composite reliabilities and average variance extracted were computed (Fornell \& Larcker, 1981). Table B.1 in appendix B presents the reliability coefficients. The construct reliabilities for the reflective constructs are all above the ideal level of 0.80 for all constructs (Mueller \& Hancock, 2008), and extracted variances are above the cut-off level of 0.50 (Hair, Tatham, \& Black, 1996). The convergent validity (i.e. the extent to which the items are truly a homogeneous set of indicators of the underlying reflective construct) was assessed using the factor loadings. Most of the standardized factor loadings are higher than 0.70 and significant at $p$-values of 0.01 (see table B.1, appendix B), which offers evidence of the convergent validity of the reflective measurements.

To evaluate the validity of the formative construct, we follow the suggestion by Hair et al. (2011). We examined each indicator's loading (absolute importance) and weight (relative importance) and used bootstrapping procedure (5000 bootstrap samples) to assess the 
significance of the loadings. All loadings (except for Env2) were significant at the level of 0.05, supporting the indicator's relevance in providing content to the respective formative constructs (Cenfetelli \& Bassellier, 2009). A potential reason for the lack of significance with respect to Env2 could be the existence of heterogeneous data structures (Hair et al., 2011). Therefore, we examined whether heterogeneity affects the coefficients in formative measurement constructs. This analysis was done using the finite mixture PLS (FIMIX-PLS) method (Ringle, Wende, \& Will, 2010). The results did not support deletion of the items. An indicator's information can become redundant due to high levels of multicollinearity in the formative measurement construct (Hair et al., 2011). To determine redundancy, we examined the degree of multicollinearity in the formative indicators by calculating the variance inflation factor (VIF). The results indicated no multicollinearity problems (VIF values were below 3) (Cassel, Hackl, \& Westlund, 1999).

We proceeded to examine the discriminant validity of the constructs, and further, possible biases of the common method. First, correlations between each pair of constructs were at acceptable levels (equal or less than 0.464 ), providing evidence of discriminant validity (see table B.2, appendix B). Second, the Fornell and Larcker's (1981) criterion was applied, in which the square root of average variance extracted (AVE) of any two constructs should be larger than the correlation coefficient between the constructs (Fornell \& Larcker, 1981). The results show that all pairs of the reflective constructs fulfilled this requirement (see table B.2, appendix B). The analysis supports a high degree of discriminant validity with respect to the constructs involved.

Common methods bias was diagnosed by using the single method factor test (Podsakoff, MacKenzie, Lee, \& Podsakoff, 2003). This test involves adding a first-order factor with all the measures as indicators to our measurement model to determine the potential effects on the relationships between the constructs. The results showed that the relationships between the 
constructs (correlations) and the significance of these relationships did not change in the single factor model in comparison with the proposed model, allowing us to exclude potentially biasing effects of the common method.

\subsection{Estimation of the structural model}

We carried out the estimation following a hierarchical process. To verify the mediating effects of behavioral commitment and communication, a number of conditions must hold (Baron and Kenny, 1986):

(1) Customer orientation should have a significant main effect on performance (Model A); and

(2) Customer orientation should have a significant main effect on the mediators (i.e. behavioral commitment and communication) (Model B and Model D);

(3) Behavioral commitment and communication should have a significant mediating effect on export performance, and the direct effect of customer orientation on export performance should become smaller in absolute value (partial mediation) or insignificant (full mediation) when the path between the mediators and export performance is opened (Model C and Model E).

In Model F, we test the joint mediating effect of communication and behavioral commitment on export performance (i.e. we open the path Communication $\longrightarrow$ Behavioral commitment). The structural models were tested in SmartPLS 2.0, and the significance of each path coefficient was assessed by means of a bootstrapping procedure with 5000 runs.

\section{Results}

We examined the overall model fit by examining the number of significant relationships among the constructs, the $\mathrm{R}^{2}$ measures, that is, the explained variance of the endogenous latent 
variables (Hortinha et al., 2011) and the goodness-of-fit (GoF) criteria (Tenenhaus, Vinzi, Chatelin, \& Lauro, 2005). Table B.3 (see appendix B) shows the path coefficients and the model-fit criteria for the structural model. More than $50 \%$ of the tested relationships were significant in a model excluding the control variables. The model predicted about $23 \%$ of the variance in each performance measure, which, based on the rule of thumb, could be described as moderate effect size. The values also satisfy the minimum of $10 \%$ for the R-square of the endogenous variables (Hortinha et al., 2011). We obtained a GoF value of 0.381, which exceeds the baseline value of 0.36 and allows us to conclude that our model performs well.

To assess the nomological validity of the model, we controlled for the possible effects of length of relationship between the business partners, firm size, and uncertainties in the environment. The results (table B.3, appendix B) show that the environmental uncertainty in the export market has a significant positive effect on satisfaction with the margins $(\beta=0.362, t$ $=3.154, p<0.01)$, and the level of complaints $(\beta=0.262, t=2.593, p<0.01)$. The firm size and the length of relationship do not influence the performance measures significantly. The inclusion of the covariates did not change the estimates of the relationships hypothesized, compared with analyses that omitted the covariates. $^{2}$

\subsection{Testing for mediating effects}

As described in section 3.4, we followed Baron and Kenny's (1986) approach to test the mediating effects of behavioral commitment and communication (see table B.4, appendix B).

- According to Model A, customer orientation has a significant main effect on the three indicators of export performance (i.e. margins, payment capability, and level of complaints). The main effects of customer orientation on behavioral

\footnotetext{
${ }^{2}$ The effect of cultural distance on performance was also tested, and the results showed that there was no significant relation between these two constructs. In the same way as with the other covariates, cultural distance did not change the estimates of the hypothesized relationships. The classification of the countries targeted for export into similar and dissimilar culture groups was guided by the country clustering worked out by Ronen and Shenkar (1985) and Chetty, Eriksson, and Lindbergh (2006).
} 
commitment and communication are statistically significant in Model B and Model D, respectively. The first conditions for behavioral commitment and communication to exert a mediating effect on the relationship customer orientation - export performance are fulfilled.

- In Model C, the relationship between the mediator behavioral commitment and payment capability is significant, and the main effect of customer orientation on payment capability becomes insignificant, which suggests full mediation of the relationship customer orientation - payment capability from the mediator behavioral commitment, in support for $H_{1.2}$. Although customer orientation has a significant main effect on margins and level of complaints (Model $A$ ), this effect is not mediated through behavioral commitment, which means that $H_{1.1}$ and $H_{1.3}$ are not supported.

- In Model E, the relationship between the mediator communication and payment capability, and between communication and level of complaints, are significant. The main effects of customer orientation on payment capability and customer orientation on level of complaints again become non-significant with the entry of communication as a mediator in the model. This finding strongly supports $H_{2.2}$ and $H_{2.3 .}$ Communication does not explain the effect of customer orientation on the margins, which means that $H_{2.1}$ is not supported.

- While communication significantly affected payment capability in Model E $(b=$ $.329, t$-value $=4.126, p<0.001)$, the strength of the relationship diminished in Model $F(b=.262, t$-value $=3.24, p<0.001)$ with the entry of the mediating effect of behavioral commitment. This finding is evidence of a partly mediating effect of behavioral commitment on the communication - payment capability relationship, in support for $H_{3.2}$. Further, as reflected in Model F, behavioral 
commitment does not seem to mediate the effect of communication on margins and level of complaints, which means that $H_{3.1}$ and $H_{3.3}$ are not supported.

\section{Discussion and conclusions}

This research contributes to understanding how customer orientation relates to performance in exporter - importer relationships. We examine two relational qualities behavioral commitment and communication - through which customer orientation influences performance measures important to the exporter, such as satisfaction with the margins, customer's payment capability, and level of complaints. The study is rooted in the relational paradigm, which is based on the assumption that building long-term relationships leads to high

performing business (e.g. Styles et al., 2008). This study contributes to research focusing on the export marketing context in several ways.

First, it shows that the effect of customer orientation on satisfaction with the customer's payment capability is fully mediated by the exporter's behavioral commitment. Customer orientation and behavioral commitment are both concerned with the customer's needs, although very different needs. A customer-oriented firm aims at offering the best solutions (product and services supporting the deliveries) to the customer in order to achieve economic advantages. We find that customer orientation promotes behavioral commitment, that is, the exporter's willingness to offer special assistance in order to signify that the firm appreciates the relationship and is motivated to make an effort to ensure that the relationship is maintained. This implies that the exporter is prepared to offer special assistance, such as a flexible payment schedule, when a customer whom the firm wants to sustain a long-term relationship with is in a difficult economic situation. Thus, behavioral commitment, which implies a long-term perspective on the relationship, can significantly affect the exporter's satisfaction with the customer's payment schedule and thereby improve the economic performance. 
Second, we find that behavioral commitment does not mediate the customer orientation's influence on the exporter's satisfaction with the margins. That is, expending extra efforts to help the customer such as offering extended credit and flexible payment schedules or accepting unfavorable orders has neither positive nor negative effects on the exporter's satisfaction with the margins. This is an important finding because it shows that offering help when the customer asks for it does not imply any negative consequences for the exporter's perceived financial performance in terms of margins. Third, our findings do not support the view that behavioral commitment mediates the relationship between customer orientation and customer's level of complaints. This result shows that offering special assistance only when the customer asks for it is not a viable strategy to reduce the number of customer complaints. Instead, our research shows that two-way communication has a key role in ensuring that customer-oriented firms achieve satisfaction with the level of complaints.

The importance of communication as an intervening variable demonstrates the influential role of the individual person in mediating and reinforcing the firm's customer orientation. Customer orientation at the firm level acts through salespeople, whose main objective is to communicate with the customers in order to solve their problems (e.g. Cross et al., 2007; Gounaris, 2005; Phan et al., 2005). Two-way communication makes the exporter well aware of the customer's needs, which ensures that the deliveries are in accordance with the customer's expectations to a greater extent, resulting in fewer complaints.

Fifth, customer-oriented firms improve satisfaction with the customer's capability of paying through communication. Communication involves sharing information that is of any use to the other part and may include information about the financial capacity of the customer. This kind of information gives the exporter an opportunity to make decisions regarding which customer relations the firm wants to sustain, leading to a higher level of customer's capability of payment. Consequently, a high level of information sharing could be considered as a 
safeguarding mechanism because it contributes to better decisions (Heide \& John, 1992; Phan et al., 2005). Communication also influences the customer's capability of payment through behavioral commitment. Frequent sharing of information strengthens the ties between the exporter and the importer, which prepares the way for helping the customer when this is asked for. Thus, our study also supports the joint mediating role of communication and behavioral commitment in the customer orientation - capability of payment relationship.

Sixth, communication does not mediate the relationship customer orientation exporter's satisfaction with the margins. In other words, frequent and informal sharing of expectations and information that is of any use to the other party does not necessarily help the exporter to achieve satisfactory margins. This indicates that the exporter needs to be aware of what kind of shared information is likely to influence the financial performance. Ural's (2009) study shows for example that sharing confidential information and exchanging views on strategic issues improve the financial performance (i.e. profitability, sales volume, growth), while sharing of formal and informal information does not.

Finally, the results show that the easier it is to predict the demand trends, and the more stable the environment is in terms of import controls, rate of exchange, and economic development, the more likely it is that the margins and the levels of complaints are satisfactory. This suggests that the planning and implementation of the deliveries are more efficient in stable markets, leading to fewer errors and thus fewer complaints. The environment's positive effect on the margins confirms that export pricing is not only influenced by the firm's own efforts, but also by environmental factors which the exporter is not in control of (e.g. Tzokas, Hart, Argouslidis, \& Saren, 2000). 


\subsection{Managerial implications}

Customer orientation helps build business relationships in export markets. Therefore, managers should allocate resources to the development of customer orientation capabilities, such as effective routines for dealing with customers' complaints, providing deliveries that match customers' requests, and regular evaluations of customers' satisfaction. These customeroriented practices facilitate communication and behavioral commitment, which are key behaviors promoting the achievement of important performance objectives. In order to succeed with the implementation of customer orientation, contact personnel need to get sufficient training so that they are well prepared to implement customer-oriented practices effectively when dealing with their customers (Cross et al., 2007).

Moreover, the manager should allocate resources to maintain a high level of communication and behavioral commitment because these relational qualities have positive consequences for important performance objectives, i.e. high satisfaction with the customers' capability of paying. Because exporters are concerned about the payment capability of the customers, they have to make sure that important information is shared right from the outset of a new business relationship. This prepares the firm for selecting those customers that have an acceptable financial strength. However, long-term customers may face a financial difficult situation. Finding a solution through communication and offering assistance such as a flexible payment schedule in time, rather than holding on to the established business conditions of the firm and waiting for them to be fulfilled, is a strategy to maintain the capability of payment at a satisfactory level as well as to sustain the relationship. Besides, the level of complaints will be kept on a satisfactory level if the exporter maintains a close two-way communication with the customers. Contact personnel should therefore be selected not only based on their professional qualifications, but also on their competence in providing support when the customer needs it, as well as in managing communication with their foreign business partners. 
The margins and level of complaints could become more in line with managers' expectations by establishing business relations in stable markets. In an unstable environment, the manager may choose to put less emphasis on margins and consider other objectives (such as customer's capability of payment) if the business relationship and the market are considered to be of great importance to the exporter.

\subsection{Limitations and future research}

This study has a number of limitations, and one of them is the single-industry focus, which limits the external validity of the study. In order to test the robustness of our model, a larger sample including other industries exporting not only from Norway, but also from other countries, must be obtained. Our study shows that the environment has a significant effect on the exporter's satisfaction with the margins. Another factor that may influence satisfaction with the margins is the buyer's power to negotiate (Cronin, Baker, \& Hawes, 1994). A study conducted in a domestic market finds that buyer power has a positive effect on the profitability of the supplying firm (Narver \& Slater, 1990). The extent to which buyer power has the same effect in an export context remains to be investigated. Factors that mediate the customer orientation - margin relationship remain to be revealed, and pricing strategy could be one potential mediator. Customer-oriented firms are highly competent when it comes to pricing methods (Argouslidis \& Indounas, 2010; Tzokas et al., 2000), and pricing strategy influences economic results (Argouslidis \& Indounas, 2010; Myers, 1997; Tan \& Sousa, 2011).

Future research could extend our knowledge regarding the consequences of behavioral commitment. Research shows that affective commitment has a positive effect and calculative commitment a negative effect on customers' intention to stay in the relationship with their suppliers (Gounaris, 2005). It could be valuable to investigate the customer's intentions to stay as a mediator in the behavioral commitment - performance relationship. 
This study considers only one party's perspective of a business relationship. Future research could collect data from matched dyads, and in that way, knowledge about the reciprocity in the relationship could be achieved (Kim \& Frazier, 1997a; Styles et al., 2008). Besides, self-evaluation of customer orientation should be accompanied by customers' ratings on this measure. The view of the customer is considered to be of great importance to ensure that the firm is continuously improving on this area (Deshpandé et al., 1993).

\section{References}

Agarwal, S., \& Ramaswami, S. N. (1992). Choice of foreign market entry mode: Impact of ownership, location and internationalization factors. Journal of International Business Studies, 23(1), 1-27.

Anderson, E., \& Weitz, B. (1989). Determinants of continuity in conventional industrial channel dyads. Marketing Science, 8(4), 310-323.

Anderson, E., \& Weitz, B. (1992). The use of pledges to build and sustain commitment in distribution channels. Journal of Marketing Research, 29(February), 18-34.

Appiah-Adu, K., \& Singh, S. (1998). Customer orientation and performance: A study of SMEs. Management Decision, 36(6), 385-394.

Argouslidis, P. C., \& Indounas, K. (2010). Exploring the role of relationship pricing in Industrial export settings: Empirical evidence from the UK. Industrial Marketing Management, 39, 460-472.

Armstrong, S. J., \& Overton, T. S. (1977). Estimating nonresponse bias in mail surveys. Journal of Marketing Research, 14(August), 396-402.

Aulakh, P. T., \& Kotabe, M. (1997). Antecedents and performance implications of channel integration in foreign markets. Journal of International Business Studies, 28(1), 145175.

Baker, T. L., Simpson, P. M., \& Siguaw, J. A. (1999). The impact of suppliers' perceptions of 
Reseller market orientation on key relationship constructs. Academy of Marketing Science, 27(1), 50-57.

Balakrishnan, S. (1996). Benefits of customer and competitive orientations in industrial markets. Industrial Marketing Management, 25, 257-269.

Baron, R. M., \& Kenny, D. A. (1986). The moderator-mediator variable distinction in social psychological research: Conceptual, strategic, and statistical considerations. Journal of Personality and Social Psychology, 51(6), 1173-1182.

Bello, D. C., Chelariu, C., \& Zhang, L. (2003). The antecedents and performance consequences of relationalism in export distribution channels. Journal of Business Research, 56(1), 1-16.

Bianchi, C., \& Saleh, A. (2010). On importer trust and commitment: A comparative study of two developing countries. International Marketing Review, 27(1), 55-86.

Bigné, E., Blesa, A., Küster, I., \& Andreu, L. (2004). Market orientation: An antecedent to the industrial manufacturer's power. European Journal of Marketing, 38(1/2), 175-193.

Blesa, A., \& Bigné, E. (2005). The effect of market orientation on dependence and satisfaction in dyadic relationships. Marketing Intelligence \& Planning, 23(3), 249265.

Bloemer, J., Pluymaekers, M., \& Odekerken, A. (2013). Trust and affective commitment as energizing forces for export performance. International Business Review, 22(2), 363380 http://dx.doi.org/10.1016/j.ibusrev.2012.05.002 (research paper).

Brown, J. R., Lusch, R. F., \& Nicholson, C. Y. (1995). Power and relationship commitment: Their impact on marketing channel member performance. Journal of Retailing, 71(4), $363-392$.

Byrne, B. M. (2010). Structural Equation Modeling with AMOS. Basic Concepts, 
Applications, and Programming. (2 $2^{\text {nd }}$ ed.). New York: Routledge. Taylor \& Francis Group.

Cadogan, J. W., Diamantopoulos, A., \& Siguaw, J. A. (2002). Export market-oriented activities: Their antecedents and performance consequences. Journal of International Business Studies, 33(3), 615-626.

Cassel, C., Hackl, P., \& Westlund, A. H. (1999). Robustness of partial least-squares method for estimating latent variable quality structures. Journal of Applied Statistics, 26(4), 435446.

Cavusgil, S. T., \& Zou, S. (1994). Marketing strategy-performance relationship: An investigation of the empirical link in export market venture. Journal of Marketing, $58(1), 1-21$.

Cenfetelli, R. T., \& Bassellier, G. (2009). Interpretation of formative measurement in information systems research. MIS Quarterly, 33(4), 689-708.

Chetty, S., Eriksson, K., \& Lindbergh, J. (2006). The effect of specificity of experience on a firm's perceived importance of institutional knowledge in ongoing business. Journal of International Business Studies, 37, 699-712.

Chang, S.-J., van Witteloostuijn A., \& Eden L. (2010). From the editors: Common method variance in international business research. Journal of International Business Studies, $41,178-184$

Cooper, R. G., \& Kleinschmidt, E. J. (1985). The impact of export strategy on export sales performance. Journal of International Business Studies, 16(1), 37-55.

Coote, L. V., Forrest, E. J., \& Tam, T. W. (2003). An investigation into commitment in nonWestern industrial marketing relationships. Industrial Marketing Management, 32, 595604.

Cronin Jr., J. J., Baker, T. L., \& Hawes, J. M. (1994). An assessment of the role performance 
measurement of power-dependency in marketing channels. Journal of Business Research, 30(3), 201-210.

Cross, M. E., Brashear, T. G., Rigdon, E. E., \& Bellenger, D. N. (2007). Customer orientation and salesperson performance. European Journal of Marketing, 41(7/8), 821-835.

Day, G. S. (1994). The capabilities of market-driven organizations. Journal of Marketing, 58(October), 37-52.

De Ruyter, K., Moorman, L., \& Lemmink, J. (2001). Antecedents of commitment and trust in customer-supplier relationships in high technology markets. Industrial Marketing Management, 30(2), 271-286.

Deshpandé, R., Farley, J. U., \& Webster, F. E., Jr. (1993). Corporate culture, customer orientation, and innovativeness in Japanese firms: A quadrad analysis. Journal of Marketing, 57(January), 23-37.

Deshpandé, R., Farley, J. U., \& Webster, F. E., Jr. (1997). Factors affecting organizational performance: A five-country comparison. Working Paper, report, No. 97-108, May Cambridge: MSI

Diamantopoulos, A. (Ed.). (1998). From the guest editor. Journal of International Marketing, 6(3), 3-6.

Dwyer, F. R., Schurr, P. H., \& Oh, S. (1987). Developing buyer-seller relationships. Journal of Marketing, 5(April), 11-27.

Evangelista, F. U. (1994). Export performance and its determinants: Some empirical evidence from Australian manufacturing firms. Advances in International Marketing, (6), 207229.

Fornell, C., \& Larcker, D. F. (1981). Evaluating structural equation models with unobservable variables and measurement error. Journal of Marketing Research, 18(1), 39-50.

Frazier, G. L. (1983). On the measurement of interfirm power in channels of distribution. 
Journal of Marketing Research, 20(2), 158-166.

Geyskens, I. G., Steenkamp, J.-B. E. M., Scheer, L. K., \& Kumar, N. (1996). The effect of trust and interdependence on relationship commitment: A trans-Atlantic study. International Journal of Research in Marketing, 13, 303-317.

Goodman, L. E., \& Dion, P. A. (2001). The determinants of commitment in the distributormanufacturer relationship. Industrial Marketing Management, 30, 287-300.

Gounaris, S. P. (2005). Trust and commitment influences on customer retention: Insights from business-to-business services. Journal of Business Research, 58, 126-140.

Granovetter, M. (1985). Economic action and social structure: The problem of embeddedness. American Journal of Sociology, 91(3), 481-510.

Gripsrud, G., Solberg, C. A., \& Ulvnes, A. M. (2006). The effect of information collection behaviour on market performance: The role of partner relationships. Advances in International Marketing, 16, 135-155.

Grönroos, C. (1989). Defining marketing: A market-oriented approach. European Journal of Marketing, 23(1), 52-60.

Hair, J. F., Jr., Anderson, R. E., Tatham, R. L., \& Black, T. W. (1996). Multivariate data analysis. ( $5^{\text {th }}$ ed.). Upper Saddle River: Prentice Hall.

Hair, J. F., Ringle C. M., \& Sarstedt, M. (2011). PLS-SEM: Indeed a silver bullet. Journal of Marketing Theory and Practice, 19(2), 139-151.

Han, J. K., Kim, N., \& Srivastava, R. K. (1998). Market orientation and organizational performance: Is innovation a missing link? Journal of Marketing, 62(4), 30-45.

Heide, J. B., \& John, G. (1992). Do norms matter in marketing relationships? Journal of Marketing, 56(April), 32-44. 
Hortinha, P., Lages, C., \& Lages, L.F. (2011). The trade-off between customer and technology orientations: Impact on innovation capabilities and export performance. Journal of International Marketing, 19(3), 36-58.

Hult, G. T. M., \& Ketchen, Jr., D. J. (2001). Does market orientation matter?: A test of the relationship between positional advantage and performance. Strategic Management Journal, , 22(9), 899-906.

Humphreys, M. A. \& Williams, M. R. (1996). Exploring the relative effects of salesperson Interpersonal process attributes and technical product attributes on customer satisfaction. The Journal of Personal Selling and Sales Management, 16(3), 47-57.

Håkansson, H. (1982). International marketing and purchasing of industrial goods: An interaction approach. John Wiley \& Sons: US.

Katsikeas, C. S., Skarmeas, D., \& Bello, D. C. (2009). Developing successful trust-based international exchange relationships. Journal of International Business Studies, 40, 132-155.

Kim, K., \& Frazier, G. (1997a). Measurement of distributor commitment in industrial channels of distribution. Journal of Business Research, (40), 139-154.

Kim, K., \& Frazier, G. (1997b). On distributor commitment in industrial channels of distribution: A multicomponent approach. Psychology \& Marketing, 14(8), 847-877.

Kim, S. K., Hibbard, J. D., \& Swain, S. D. (2011). Commitment in marketing channels: Mitigator or aggravator of the effects of destructive acts? Journal of Retailing, 87(4), $521-539$.

Kumar, N., Scheer, L. K., Steenkamp, J.-B. E.M. (1995). The effects of supplier fairness on vulnerable resellers. Journal of Marketing Research, 32(1), 54-65.

Kumar, E. J. V., Venkatesan, R., \& Leone, R. P. (2011). Is market orientation a source of sustainable competitive advantage or simply the cost of competing? Journal of 
Marketing, 75(January), 16-30.

LaBahn, D. W., \& Harich, K. R. (1997). Sensitivity to national business culture: Effects on U.S.-Mexican channel relationship performance. Journal of International Marketing, 5(4), 29-51.

Lages, L. F. (2000). A conceptual framework of the determinants of export performance. Journal of Global Marketing, 13(3), 29-51.

Leonidas, C., Katsikeas, C. S., \& Hadjimarcou, J. (2002). Building successful export business relationships: A behavioural perspective. Journal of International Marketing, 10(3), 96-115.

Leonidou, L. C., Palihawadana, D., Chari, S., \& Leonidou, C. N. (2011). Drivers and outcomes of importer adaptation in international buyer-seller relationships. Journal of World Business, 46, 527-543.

Leonidou, L. C., Samiee, S., Aykol, B., \& Talias, M. A. (2014). Antecedents and outcomes of exporter-importer relationship quality: Synthesis, meta-analysis, and directions. Journal of International Marketing, (22), 2, 21-46.

Lohtia, R., Bello, D. C., Yamada, T., \& Gilliland, D. I. (2005). The role of commitment in foreign-Japanese relationships: Mediating performance for foreign seller in Japan. Journal of Business Research, 58, 1009-1018.

Madsen, T. K. (1989). Successful export marketing management: Some empirical evidence. International Marketing Review, 6(4), 41-57.

Macneil, I. R. (1978). Contracts: Adjustments of long-term economic relations under classical, neoclassical, and relational contract law. Northwestern University Law Review, 76(6), 854-905.

Medlin, C. J., Aurifeille, J.-M., \& Quester, P. G. (2005). A collaborative interest model of 
relational coordination and empirical results. Journal of Business Research, 58, 214222.

Mohr, J., \& Nevin, J. R. (1990). Communication strategies in marketing channels: A theoretical perspective. Journal of Marketing, 54(4), 36-51.

Morgan, R. M., \& Hunt, S. D. (1994). The commitment-trust theory of relationship marketing. Journal of Marketing, 58(July), 20-38.

Mueller, R. O., \& Hancock, G. R. (2008). Best practices in structural equation modeling. In J. W. Osborne (Ed.). Best practices in quantitative methods (pp. 488-508). Thousand Oaks, CA: Sage Publications, Inc.

Murray, J. Y., Gao, G. Y., \& Kotabe, M. (2011). Market orientation and performance of export ventures: the process through marketing capabilities and competitive advantages. Journal of the Academy of Marketing Science, 39(2), 252-269.

Myers, M. B. (1997). The pricing of export products: Why aren't managers satisfied with the results? Journal of World Business, 32(3), 277-289.

Narver, J. C., \& Slater, S. F. (1990). The effect of a market orientation on business profitability. Journal of Marketing, October, 20-35.

Nes, E. B., Solberg, C. A., \& Silkoset, R. (2007). The impact of national culture and communication on exporter-distributor relations and on export performance. International Business Review, 16(4), 405-424.

Noordewier, T. G., John, G., \& Nevin, J. R. (1990). Performance outcomes of purchasing arrangements in industrial buyer-vendor relationships. Journal of Marketing, 54(4), 8093.

O’Grady, S., \& Lane, H. W. (1996). The psychic distance paradox. Journal of International Business Studies, 2nd quarter, 309-333.

Parasuraman, A. (1987). Customer-oriented corporate cultures are crucial to services 
marketing success. Journal of Services Marketing, 1(1), 39-46.

Pelham, A. M. (2000). Market orientation and other potential influences on performance in small and medium-sized manufacturing firms. Journal of Small Business Management, 38(1), 48-67.

Pettersen, I. B. (2005). A multi-level perspective on exit intention in business relationships. What are the effects of specific investments in international business dyads in the seafood industry? Doctoral Dissertations. Bergen: Norwegian School of Economics.

Phan, M. C. T., Styles, C. W., \& Patterson, P. G. (2005). Relational competency's role in Southeast Asia business partnerships. Journal of Business Research, 58, 173-184.

Pierce, J. L., \& Delbecq, A. L. (1977). Organization structure, individual attitudes and Innovation. The Academy of Management Review, 2(1), 27-37.

Podsakoff, P. M., MacKenzie, S. B., Lee, J.-Y., \& Podsakoff, N. P. (2003). Common method biases in behavioral research: A critical review of the literature and recommended remedies. Journal of Applied Psychology, 88, 879-903.

Racela, O. C., Chaikittisilpa, C., \& Thoumrungroje, A. (2007). Market orientation, international business relationships and perceived performance. International Marketing Review, 24(2), 144-163.

Raven, P. V., McCullough, J. M., \& Tansuhaj, P. S. (1994). Environmental influences and decision-making uncertainty in export channels: Effects on satisfaction and performance. Journal of International Marketing, 2(3), 37-59.

Rindfleisch, A., \& Heide, J. B. (1997). Transaction cost analysis: Past, present, and future applications. Journal of Marketing, 61(4), 30-54.

Ringle, C. M., Wende S., \& Will, A. (2005). SmartPLS 2.0 (beta). Hamburg: University of Hamburg. Retrieved from http://www.smartpls.de. 
Ringle, C. M., Wende S., \& Will, A. (2010). Finite mixture partial least squares analysis: methodology and numerical examples. In V. E. Vinzi, W. W. Chin, J. Henseler, \& H. Wang (Eds.). Handbook of Partial Least Squares: Concepts, Methods and Applications in Marketing and Related Fields (pp. 195-218). Berlin: Springer.

Ronen, S., \& Shenkar, O. (1985). Clustering countries on attitudinal dimensions: A review and synthesis. Academy of Management Review, 10(3), 435-454.

Rose, G. M., \& Shoham, A. (2002). Export performance and market orientation. Establishing an empirical link. Journal of Business Research, 55(3), 217-225.

Rosson, P. J., \& Ford, I. D. (1982). Manufacturer - overseas distributor relations and export performance. Journal of International Business Studies, 13(2), 57-72.

Shankarmahesh, M. N., Ford, J. B., \& LaTour, M. S. (2004). Determinants of satisfaction in sales negotiations with foreign buyers: perceptions of US export executives. International Marketing Review, 21(4/5), 423-446.

Siguaw, J. A., Simpson, P. M., \& Baker, T. L. (1998). Effects of supplier market orientation on distributor market orientation and the channel relationship: The distributor perspective. Journal of Marketing, 62(3), 99-111.

Siguaw, J. A., Brown, G., \& Widing, II, R. E. (1994). The influence of the market orientation of the firm on sales force behavior and attitudes. Journal of Marketing Research, 31(February), 106-116.

Skarmeas, D., Katsikeas, C. S., \& Schlegelmilch, B. B. (2002). Drivers of commitment and its impact on performance in cross-cultural buyer-seller relationships: The importer's perspective. Journal of International Business Studies, 33(4), 757-783.

Slater, S. F., \& Narver, J. C. (1994). Market orientation, customer value, and superior performance. Business Horizons, March-April, 22-28.

Smirnova, M., Naudé, P., Henneberg, S. C., Mouzas, S., \& Kouchtch, S. P. (2011). The 
impact of market orientation on the development of relational capabilities and performanc outcomes: The case of Russian industrial firms. Industrial Marketing Management, 40(1), 44-53.

Solberg, C. A., \& Olsson, U. H. (2010). Management orientation and export performance: The case of Norwegian ICT companies. Baltic Journal of Management, 5(1), 28-50.

Sousa, C. M. P., Martinez-Lopez, F. J., \& Coelho, F. (2008). The determinants of export Perforformance: A review of the research in the literature between 1998 and 2005. International Journal of Management Review, 10(4), 343-374.

Steinman, C., Deshpandé, R., \& Farley, J. U. (2000). Beyond market orientation: When customers and suppliers disagree. Journal of the Academy of Marketing Science 28(1), 109-119.

Strong, C. A., \& Harris, L. C. (2004). The drivers of customer orientation: An exploration of relational, human resource and procedural tactics. Journal of Strategic Marketing, 12(3), 183-204.

Styles, C., \& Ambler, T. (1994). Successful export practice: The UK experience. International Marketing Review, 11(6), 23-47.

Styles, C., Patterson, P. G., \& Ahmed, F. (2008). A relational model of export performance. Journal of International Business Studies, 39(5), 880-900.

Styles, C. (1998). Export performance measures in Australia and the United Kingdom. Journal of International Marketing, 6(3), 12-36.

Tan, Q., \& Sousa, C. M. P. (2011). Research on export pricing: Still moving toward maturity. Journal of International Marketing, 19(3), 1-35.

Taylor, C. R., Kim, K. H., Ko, E., Park, M. H., Kim, D. R., \& Moon, H. I. (2008). Does 
having a market orientation lead to higher levels of relationship commitment and business performance? Evidence from the Korean robotics industry. Industrial Marketing Management, 37, 825-832.

Tenenhaus, M., Vinzi, V. E., Chatelin, Y.-M., \& Lauro, C. (2005). PLS Path modeling. Computational Statistics and Data Analysis, 48(1), 159-205.

Tzokas, N., Hart, S., Argouslidis, P., \& Saren, M. (2000). Industrial export pricing practices in The United Kingdom. Industrial Marketing Management, 29, 191-204.

Ural, T. (2009). The effects of relationship quality on export performance. A classification of small and medium-sized Turkish exporting firms operating in single export-market ventures. European Journal of Marketing, 43(1/2), 139-168.

Voss, K. E., Johnson, J. L., Cullen, J. B., Sakano, T., \& Takenouchi, H. (2006). Relational exchange in US-Japanese marketing strategic alliances. International Marketing Review, 23(6), 610-635.

Zhang, C., Cavusgil, S. T., \& Roath, A. S. (2003). Manufacturer governance of foreign distributor relationships: Do relational norms enhance competitiveness in the export market? Journal of International Business Studies, 34, 550-566.

Zhou, K. Z., Brown, J. R., Dev, C. S., \& Agarwal, S. (2007). The effects of customer and Competitor orientations on performance in global markets: a contingency analysis. Journal of International Business Studies, 38, 303-319. 
Appendix A.

Table A.1 Constructs and indicators

\begin{tabular}{|c|c|c|c|}
\hline Label & Constructs and indicators & Mean & $S D$ \\
\hline & Customer orientation (CO) & & \\
\hline Cus 1 & $\begin{array}{l}\text { In our firm it is the practice to take steps immediately when a } \\
\text { customer has a complaint. }\end{array}$ & 4.141 & 0.592 \\
\hline Cus 2 & $\begin{array}{l}\text { In our firm it is the practice to respond as soon as possible to the } \\
\text { customers' requests. }\end{array}$ & 4.217 & 0.569 \\
\hline Cus 3 & $\begin{array}{l}\text { The firm has a very good understanding of how the customers } \\
\text { judge the quality of products and the customer service. }\end{array}$ & 4.066 & 0.539 \\
\hline \multirow[t]{2}{*}{ Cus4 } & $\begin{array}{l}\text { The firm regularly evaluates the satisfaction of the customers with } \\
\text { regard to quality of the product and the customer service }\end{array}$ & 3.518 & 0.842 \\
\hline & Behavioral commitment (BC) & & \\
\hline Beh1 & Our firm makes adjustments for this customer when necessary. & 4.150 & 0.716 \\
\hline Beh2 & $\begin{array}{l}\text { Our firm goes to great lengths to help this customer when problems } \\
\text { occur. }\end{array}$ & 4.415 & 0.566 \\
\hline \multirow[t]{2}{*}{ Beh3 } & Our firm responds immediately when this customer asks for help. & 4.434 & 0.552 \\
\hline & Communication $(C)$ & & \\
\hline Infl & $\begin{array}{l}\text { Exchange of information between this customer and me takes place } \\
\text { frequently and informally. }\end{array}$ & 3.952 & 0.735 \\
\hline $\operatorname{Inf} 2$ & $\begin{array}{l}\text { This business relationship is characterized by two-way } \\
\text { communication. }\end{array}$ & 4.009 & 0.654 \\
\hline $\operatorname{Inf} 3$ & $\begin{array}{l}\text { In this business relationship, information that is of any use to the } \\
\text { other part is given. }\end{array}$ & 3.792 & 0.824 \\
\hline Inf4 & $\begin{array}{l}\text { In this business relationship we communicate our expectations to } \\
\text { each other. }\end{array}$ & 3.773 & 0.720 \\
\hline \multirow[t]{2}{*}{$\operatorname{Inf5}$} & $\begin{array}{l}\text { In this business relationship, each of us informs the other part } \\
\text { about events or changes that are of significance to the other part. }{ }^{\text {a }}\end{array}$ & 3.886 & 0.772 \\
\hline & Performance $(P)$ & & \\
\hline Margins & $\begin{array}{l}\text { Our firm is very satisfied with the percentage margin achieved } \\
\text { from this customer. }\end{array}$ & 3.594 & 0.753 \\
\hline $\begin{array}{l}\text { Paying } \\
\text { capability }\end{array}$ & Our firm is very satisfied with this customer's capability of paying & 4.076 & 0.927 \\
\hline \multirow[t]{2}{*}{ Complaints } & This customer's level of complaints is very satisfactory. & 3.962 & 0.742 \\
\hline & Length $(L)$ & & \\
\hline \multirow[t]{2}{*}{ Length } & Length of relationship (years) & 7.358 & 5.795 \\
\hline & Firm size $(S)$ & & \\
\hline \multirow[t]{2}{*}{ Empl } & Number of employees & 21.25 & 39.44 \\
\hline & Environment $(E)$ & & \\
\hline Envl & Demand trends & 3.217 & 0.861 \\
\hline Env2 & Import controls & 3.495 & 1.177 \\
\hline Env3 & Rate of exchange & 2.697 & 1.090 \\
\hline Env4 & Economic development & 3.169 & 0.786 \\
\hline
\end{tabular}

${ }^{\mathrm{a}}$ Inf5 was deleted from the model due to cross loadings. 


\section{Appendix B.}

Table B.1 Measurement properties for the structural model (Bootstrapping estimates, Cases $=105$, samples $=5000)$

\begin{tabular}{|c|c|c|c|c|c|}
\hline Construct & Item & Loading & $\begin{array}{r}t- \\
\text { value }\end{array}$ & $C R$ & $A V E$ \\
\hline Customer orientation & $\begin{array}{l}\text { Cus1 } \\
\text { Cus2 } \\
\text { Cus3 } \\
\text { Cus } 4\end{array}$ & $\begin{array}{l}.763^{* * *} \\
.825^{* * *} \\
.847^{* * *} \\
.700^{* * *}\end{array}$ & $\begin{array}{r}14.29 \\
20.21 \\
24.71 \\
8.80\end{array}$ & .865 & .618 \\
\hline Behavioral commitment & $\begin{array}{l}\text { Beh1 } \\
\text { Beh2 } \\
\text { Beh3 }\end{array}$ & $\begin{array}{l}.588^{* * *} \\
.871^{* * *} \\
.876^{* * *}\end{array}$ & $\begin{array}{r}5.55 \\
24.44 \\
21.07\end{array}$ & .829 & .624 \\
\hline Communication & $\begin{array}{l}\text { Inf1 } \\
\text { Inf2 } \\
\text { Inf3 } \\
\text { Inf4 }\end{array}$ & $\begin{array}{l}.772^{* * *} \\
.863^{* * *} \\
.744^{* * *} \\
.755^{* * *}\end{array}$ & $\begin{array}{l}16.82 \\
28.01 \\
11.05 \\
13.73\end{array}$ & .864 & .616 \\
\hline Performance & $\begin{array}{l}\text { Margins } \\
\text { Paying } \\
\text { capability } \\
\text { Complaints }\end{array}$ & $\begin{array}{l}1.00 \\
1.00 \\
1.00\end{array}$ & $\begin{array}{l}\text { fixed } \\
\text { fixed } \\
\text { fixed }\end{array}$ & & \\
\hline $\begin{array}{l}\ln (\text { Length })^{a} \\
\ln (\text { Firm size })^{a}\end{array}$ & $\begin{array}{l}\text { Length } \\
\text { Empl }\end{array}$ & $\begin{array}{l}1.00 \\
1.00\end{array}$ & $\begin{array}{l}\text { fixed } \\
\text { fixed }\end{array}$ & & \\
\hline Environment & $\begin{array}{l}\text { Env1 } \\
\text { Env2 } \\
\text { Env3 } \\
\text { Env4 }\end{array}$ & $\begin{array}{c}.268^{*} \\
-.150 \\
.263^{* * *} \\
.757^{* * *}\end{array}$ & $\begin{array}{l}2.52 \\
0.78 \\
3.86 \\
6.93 \\
\end{array}$ & & $\begin{array}{r}\text { Formative } \\
\text { construct }\end{array}$ \\
\hline
\end{tabular}

${ }^{\mathrm{a}} \ln$ - natural logarithm function.

${ }^{* * * *} p<.001 ;{ }^{* *} p<.01 ;{ }^{*} p<.05$ 
Table B.2 Descriptive statistics and correlation matrix

\begin{tabular}{|c|c|c|c|c|c|c|c|c|c|}
\hline Constructs & $\mathrm{CO}$ & $B C$ & $C$ & $M$ & $P C$ & $C P$ & $\ln L$ & $\ln S$ & $E$ \\
\hline Mean $^{\mathrm{a}}$ & 3.98 & 4.33 & 3.88 & 3.59 & 4.07 & 3.96 & 1.73 & 2.12 & 3.13 \\
\hline Std. dev. ${ }^{a}$ & .474 & .506 & .605 & .753 & .927 & .742 & .717 & 1.316 & .979 \\
\hline \multicolumn{10}{|l|}{ Correlation matrix } \\
\hline Customer orientation $(\mathrm{CO})$ & $.786^{\mathrm{b}}$ & & & & & & & & \\
\hline Behavioral commitment $(B C)$ & .464 & $.789^{\mathrm{b}}$ & & & & & & & \\
\hline Communication $(C)$ & .303 & .337 & $.784^{\mathrm{b}}$ & & & & & & \\
\hline Margins (M) & .269 & .212 & .263 & - & & & & & \\
\hline Paying capability $(P C)$ & .250 & .375 & .389 & .301 & - & & & & \\
\hline Complains $(C P)$ & .220 & .126 & .358 & .395 & .272 & - & & & \\
\hline $\ln (\text { Length of relationship })^{\mathrm{c}}(\ln L)$ & .023 & .031 & .125 & .035 & .108 & .138 & - & & \\
\hline $\ln (\text { Firm size })^{\mathrm{c}}(\ln S)$ & -.037 & -.034 & .054 & .082 & -.051 & -.075 & -.126 & - & \\
\hline Environment $(E)$ & .119 & .005 & .221 & .384 & .152 & .299 & -.133 & .081 & - \\
\hline
\end{tabular}

${ }^{a}$ Mean and standard deviation of the variables are deterministically calculated based on the individual items.

${ }^{b}$ Numbers denote the square root of AVE for reflective constructs.

${ }^{\mathrm{c}}$ ln - natural logarithm function. 
Table B.3 PLS path coefficients, communalities, $\mathrm{R}^{2}$-values, and goodness-of-fit indicators

\begin{tabular}{|c|c|c|c|}
\hline Path & Standardized coefficient & t-value & Significance \\
\hline Customer orientation $\longrightarrow$ Behavioral commitment & .402 & 4.281 & $p<.001$ \\
\hline Customer orientation $\longrightarrow$ Communication & .304 & 2.927 & $p<.01$ \\
\hline Communication $\longrightarrow$ Behavioral commitment & .215 & 2.353 & $p<.01$ \\
\hline Behavioral commitment $\longrightarrow$ Margins & .171 & 1.905 & n.s. \\
\hline Behavioral commitment $\longrightarrow$ Payment capability & .280 & 3.518 & $p<.001$ \\
\hline Behavioral commitment $\longrightarrow$ Complaints & .022 & .231 & n.s. \\
\hline Communication $\longrightarrow$ Margins & .116 & 1.378 & n.s. \\
\hline Communication $\longrightarrow$ Payment capability & .267 & 3.181 & $p<.01$ \\
\hline Communication $\longrightarrow$ Complaints & .284 & 3.106 & $p<.01$ \\
\hline \multicolumn{4}{|l|}{ Control variables } \\
\hline Length of relationship $\longrightarrow$ Margins & .066 & .911 & n.s. \\
\hline Length of relationship $\longrightarrow$ Payment capability & .072 & .857 & n.s. \\
\hline Length of relationship $\longrightarrow$ Complaints & .121 & 1.529 & n.s. \\
\hline Firm size $\longrightarrow$ Margins & .063 & .775 & n.s. \\
\hline Firm size $\longrightarrow$ Payment capability & -.054 & .597 & n.s. \\
\hline Firm size $\longrightarrow$ Complaints & -.093 & 1.187 & n.s. \\
\hline Environment $\longrightarrow$ Margins & .362 & 3.154 & $p<.01$ \\
\hline Environment $\longrightarrow$ Payment capability & .104 & .937 & n.s. \\
\hline Environment $\longrightarrow$ Complaints & .262 & 2.593 & $p<.01$ \\
\hline Model fit & Communality & $R^{2}$ & \\
\hline
\end{tabular}




\begin{tabular}{lll}
\hline Customer orientation & .618 & - \\
Behavioral commitment & .624 & .257 \\
Communication & .616 & .092 \\
Performance & & .231 \\
$\quad$ Margins & & .235 \\
$\quad$ Paying capability & & .207 \\
$\quad$ Complaints & - & - \\
$\ln$ (Length of relationship) $^{\mathrm{a}}$ (Firm size) & - & - \\
Environment $_{\text {Average }}^{\mathrm{a}}$ & - & - \\
\hline
\end{tabular}

${ }^{\mathrm{a}} \ln$ - natural logarithm function. GoF $=\sqrt{\text { Communaltty } * \overline{R^{2}}}$ 
Table B.4 PLS results on the mediating effects of behavioral commitment and communication (Bootstrapping estimates, Cases $=105$, samples $=5000)$

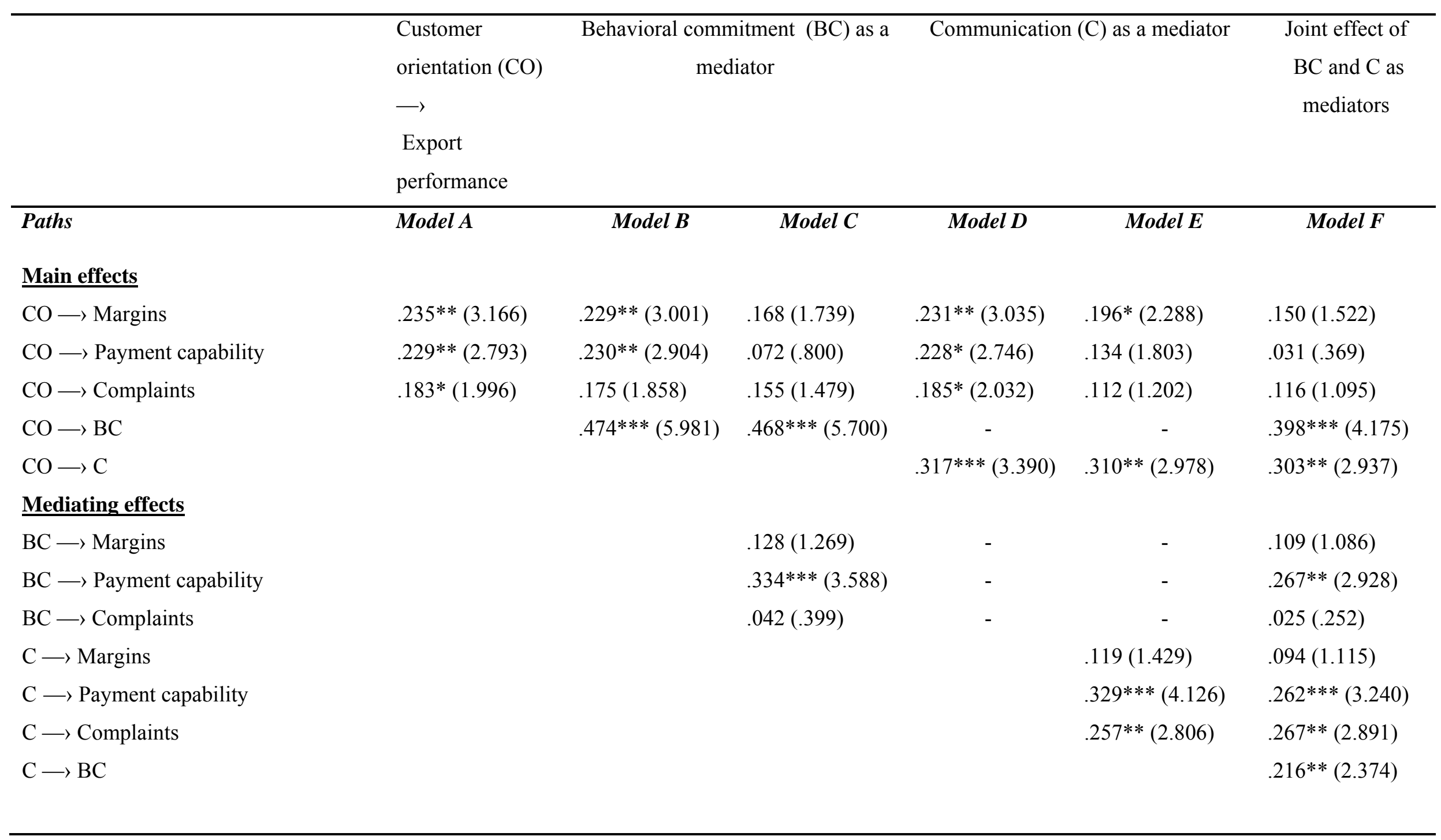




\begin{tabular}{|c|c|c|c|c|c|c|}
\hline \multicolumn{7}{|l|}{ Control variables } \\
\hline $\ln ($ Length $) \longrightarrow$ Margins & $.080(1.112)$ & $.082(1.144)$ & $.080(1.104)$ & $.080(1.092)$ & $.066(.944)$ & $.067(.942)$ \\
\hline In (Length) $\longrightarrow$ Payment capability & $.113(1.343)$ & $.114(1.372)$ & $.110(1.305)$ & $.110(1.307)$ & $.071(.843)$ & $.072(.852)$ \\
\hline $\ln ($ Length) $\longrightarrow$ Complaints & $.160 *(2.042)$ & $.161 *(2.025)$ & $.161 *(2.023)$ & $.161 *(2.002)$ & $.122(1.552)$ & $.122(1.578)$ \\
\hline $\ln ($ Firm size $) \longrightarrow$ Margins & $.072(.875)$ & $.073(.896)$ & $.075(.933)$ & $.075(.900)$ & $.068(.841)$ & $.069(.850)$ \\
\hline $\ln ($ Firm size $) \longrightarrow$ Payment capability & $-.041(.404)$ & $-.039(.383)$ & $-.035(.368)$ & $-.035(.368)$ & $-.054(.589)$ & $-.053(.587)$ \\
\hline $\ln ($ Firm size $) \longrightarrow$ Complaints & $-.072(.849)$ & $-.071(.844)$ & $-.071(.822)$ & $-.070(.826)$ & $-.089(1.118)$ & $-.089(1.103)$ \\
\hline $\ln ($ Environment $) \longrightarrow$ Margins & $.359 * * *(3.281)$ & $.363 * * *(3.244)$ & $.369 * * *(3.419)$ & $.369 * * *(3.312)$ & $.349 * *(3.120)$ & $.349 * *(3.052)$ \\
\hline $\begin{array}{l}\ln (\text { Environment }) \longrightarrow \text { Payment } \\
\text { capability }\end{array}$ & $.138(1.288)$ & $.141(1.316)$ & $.157(1.446)$ & $.157(1.466)$ & $.102(.933)$ & $.102(.944)$ \\
\hline $\ln ($ Environment $) \longrightarrow$ Complaints & $.303 * *(3.056)$ & $.306 * *(3.121)$ & $.308 * *(3.099)$ & $.307 * *(3.046)$ & $.252 * *(2.59)$ & $.252 * *(2.587)$ \\
\hline
\end{tabular}

${ }^{* *} p$-value $\leq .001 ;{ }^{* *} p$-value $\leq .01 ;{ }^{*} p$-value $\leq .05 ;{ }^{\text {ns }}$ - not significant at $p$-value of $.05 ; \mathrm{t}$-values in parenthesis. 
